\title{
Tourism Companies and Their Role in Social Responsibility in Jordan
}

\author{
Mohammad Nayef Alsarayreh ${ }^{1}$ \\ ${ }^{1}$ Al-Balqa' Applied University, Jordan \\ Correspondence: Mohammad Nayef Alsarayreh, Al-Balqa' Applied University, Jordan.
}

Received: August 15, 2018

Accepted: September 30, 2018

Online Published: October 11, 2018

doi:10.5430/ijba.v9n6p22

URL: https://doi.org/10.5430/ijba.v9n6p22

\begin{abstract}
The importance of social responsibility in tourism companies in Jordan, which has become indispensable because of the fact that it has become a topic of great interest as a result of its spread among the largest institutions in the world, is important.

The study concluded that the tourism companies give importance to the areas of social responsibility. The study concluded that the tourism companies develop the relationship with the workers in the tourism companies. The study concluded that the tourism companies are developing the relationship with the local community.

The study recommended that tourism companies' benefit from the experiences of their counterparts in the field of social responsibility, the study recommends that tourism companies implement social responsibility consistent with the sustainable development approach.
\end{abstract}

Keywords: tourism, social responsibility, tourism companies

\section{Introduction}

Corporate Social Responsibility the term emerged with the beginning of the twenty-first century in light of the mobilization of capital over everything and its control over the joints of countries and the emergence of giants and cross-continents.

The responsibility lies with the small and large business organizations that do not exceed the boundaries of the city in which they are located or the country has crossed the borders of the country and spread its branches in other countries, regional or global. It is primarily a moral responsibility.

Smart business owners know the benefits of CSR. If they are in developing societies and want to grow their organizations and develop and expand their businesses, society must grow and develop around them, although they are developed and advanced societies that have forced them to compete for CSR

If we look at the developed and civilized countries and how to protect the development of tourism, for example, Chinese companies will provide their employees with tourism and leisure trips to various different locations until a Chinese tourist group of 6400 employees at the expense of Chinese billionaires working for his company The trip has included Paris and Nice. The trip cost 33 million euros. The UAE has also received 14,000 Chinese tourists to spend 5 days of paid holidays at the expense of their companies in recognition of their efforts to make profits and the company's success.

It is the spirit of competition between companies to strengthen the strength of the institutional affiliation of their employees and as a kind of appreciation and thanks for their effort and effort and the appreciation of material and moral and human words with concepts far-reaching not understood by some.

\section{Previous Studies}

Abdul Majid Saghir (2010), Multinational Commercial Companies and Social Responsibility.

The objective of my choice of corporate social responsibility in the context of profound changes at the national and international levels is that multinational corporations have become the number one operator in the world and thus have been analyzing the nature of the latter's legal responsibility, which is increasingly playing an important role in international trade, As an economic transaction can not be ignored, in addition to the expansion of the strength of investments that countries are racing to attract.

Mohamed Falak (2018), Corporate Social Responsibility and its Role in Consumer Protection. 
The concept of social responsibility goes beyond the limits of charitable work and extends it to broader and deeper meanings for economic and social development through the establishment of principles that encourage attention to employment, society and the surrounding environment through the enactment and implementation of laws regulating CSR. This article aims at following the analytical descriptive approach to the recognition of the philosophy of corporate social responsibility and its role in protecting the rights of the consumer. He also concludes to make some recommendations for both companies and consumers.

Quality study, Sheikh, and Sogu (2009):

The study aimed to identify the extent to which liability accounting is applied in the 4 star and 5 star hotels in Jordan. The study was limited to Amman hotels only. The results of the study that the Jordanian hotels clearly identify the responsibility centers and that budget are prepared linking the actual performance of the scheme, and that there is an integrated reporting system to follow up and evaluate the disease and found that there is an effective incentive system. One of the recommendations of the study is to increase coordination between the centers of responsibility and to clarify the relationship between them and to activate the planning budgets, especially in the field of supervision. Highlighting the importance and drafting of reports. And to develop the managerial and accounting skills of the employees and their development.

Naima Yahyaoui, models of some international and Islamic companies in establishing social responsibility

The aim of this paper is to identify the nature of corporate social responsibility, the reasons for its emergence, and the most important dimensions. It will also present the experiences of some successful international and Islamic companies that contribute effectively to the development of their societies.

Hanna Fayed and others (2016) Social responsibility and its reflection on the ethics of tourism work: a proposal for a charter of business ethics in tourism companies in Egypt.

This research aims at developing a vision for a moral charter that establishes some of the controls and ethics of the professional work of the workers in the tourism sector through:

Determine the criteria of social responsibility that form the basis for building the proposed ethical charter.

B. To provide rules, controls and ethical procedures that regulate the relationship between employees in the tourism sector and the beneficiaries and provide them with solutions that are structurally appropriate and practical to the problems that may be encountered during the performance of the work.

\section{Problem of Study}

Is the trend towards the adoption of social responsibility in tourism companies in Jordan, so that economic prosperity has become linked to social responsibility in the tourism companies in Jordan?

The tourism companies in Jordan lack an interest in the so-called social responsibility in tourism companies in the tourism sector, which is the negligence of workers in the tourism sector and not follow the foundations of so-called social responsibility in tourism companies.

\section{Importance of Studying}

The importance of social responsibility in tourism companies in Jordan, which has become indispensable because of the fact that it has become a topic of great interest as a result of its spread among the largest institutions in the world is important.

\section{Objectives of the Study}

The importance of research comes from the importance of CSR in general, and the importance of research is as follows:

1). The tourism sector is one of the largest productive sectors in Jordan.

2). The tourism sector is one of the most active sectors of the labor force and the control of citizens.

3). Social responsibility in tourism companies is important for their direct and indirect reflection on the satisfaction of customers and the credibility of the company

\section{Type of Study and Methodology}

This study belongs to the analytical exploratory studies and adopts the method of collecting and analyzing data to reach the results. A total of 100 questionnaires were distributed, of which 90 were returned and 10 questionnaires 
were excluded. Therefore, we relied on questionnaire (80) Data were collected from them through the questionnaire, representing the research community and the sample of the study.

\section{Hypotheses}

1). Tourism companies give importance to areas of social responsibility.

2). Tourism companies develop the relationship with workers in tourism companies.

3). Tourism companies develop the relationship with the local community.

\section{The Practical Side}

\subsection{The Practical Field of the Study}

First: describe for respondents' demographic backgrounds

Table 1 explain description for respondents' demographic backgrounds and the job to all one of sample that work in hotels, it was as follows:

*sex: $70 \%$ of sample they are a male, $30 \%$ they are a female

*education: whereas appear that $60 \%$ of study's sample they have Bachelor degree, and $30 \%$ they have a Secondary School Certification, and $10 \%$ they have a Diploma, whereas just $6 \%$ they have $\mathrm{PhD}$, the same rate have a Master degree.

*age: whereas $25 \%$ of sample their age less than 20 , and $26 \%$ their age between $20-55$, and $30 \%$ between $40-50$, and $9 \%$ more than 51 .

*Experience years: whereas $21 \%$ of sample their experience between $11-16$ years, $20 \%$ of sample their experience 5-7 years, the same rate have a above 11, and 15\% their experience less than 6 years.

*the owner: $30 \%$ of companies their owner is special, $35 \%$ is Common, $4 \%$ is Joint.

Table 1. The respondents' demographic backgrounds

\begin{tabular}{cccc}
\hline Variable & Group of variable & Frequency & Percent \\
Sex & Male & 50 & \\
Education & Female & 30 & \\
& Secondary & 20 & 10.0 \\
& Diploma & 10 & 10.5 \\
& B. Sc & 20 & 30.5 \\
& M.Sc & 10 & 5.0 \\
Age & Ph.D & 10 & 5.0 \\
& $<30$ & 30 & 30.0 \\
& $31-40$ & 20 & 20.0 \\
& $41-50$ & 10 & 10.0 \\
Experience years & $>50$ & 20 & 15.0 \\
& $<5$ & 20 & 16.0 \\
& $6-9$ & 10 & 18.0 \\
& $10-15$ & 40 & 30.0 \\
owner & $>15$ & 10 & 20.0 \\
& Special & 30 & 40.0 \\
& Common & 40 & 40.0 \\
& Joint & 10 & 20.0 \\
\hline
\end{tabular}

\subsubsection{Instrument Stability}

* Had been tested stability of the tool by using Cronbach's Alpha coefficient, by looking on table number (2) be clear as follow:

1). Cronbach's Alpha value of dimension related to sociality responsibility was 0.2 .

2). Cronbach's Alphavalue of dimension related to Relation with employee was .0 .71 
3). Cronbach's Alphavalue of dimension related to Relation with consumer was 0.30

4). Cronbach's Alphavalue of dimension related to Local society was 0.55

5). Cronbach's Alphavalue of dimension related to Nature resource was 0.44

6). Cronbach's Alphavalue of dimension for all statements was 0.10 .

Table 2. Alpha cronbach value for study's statements

\begin{tabular}{|c|c|c|c|c|c|}
\hline Statement & extraction & Cronbach's Alpha & statement & extraction & Cronbach's Alpha \\
\hline sociality responsibility & ------ & 0.54 & 32 & 0.52 & \\
\hline 1 & 0.45 & & Local society & & 0.65 \\
\hline 2 & 0.32 & & 26 & 0.35 & \\
\hline 3 & 0.45 & & 35 & 0.23 & \\
\hline 4 & 0.75 & & 21 & 0.78 & \\
\hline Relation with employee & & & 23 & 0.87 & \\
\hline 5 & & 0.25 & 25 & 0.78 & \\
\hline 6 & 0.55 & & 23 & 0.57 & \\
\hline 7 & 0.33 & & 24 & 0.65 & \\
\hline 8 & 0.25 & & 23 & 0.47 & \\
\hline 9 & 0.14 & & 36 & 0.78 & \\
\hline 10 & 0.78 & & 35 & 0.65 & \\
\hline 11 & 0.12 & & 36 & 0.84 & \\
\hline 12 & 0.25 & & 36 & 0.87 & \\
\hline 13 & 0.85 & & 35 & 0.78 & \\
\hline 14 & 0.68 & & Nature resource & & 0.54 \\
\hline 15 & 0.76 & & 35 & 0.66 & \\
\hline 16 & 0.75 & & 39 & 0.58 & \\
\hline Relation with consumer & & 0.65 & 40 & 0.50 & \\
\hline 17 & & & 52 & 0.65 & \\
\hline 18 & 0.45 & & 34 & 0.78 & \\
\hline 19 & 0.68 & & 48 & 0.54 & \\
\hline 20 & 0.36 & & 35 & 0.65 & \\
\hline 21 & 0.32 & & All paragraphs & & 0.70 \\
\hline 22 & 0.13 & & & & \\
\hline
\end{tabular}

\subsubsection{Instrument Truth}

Was to ensure the veracity of the tool by using factor analysis to examine the extent to which phrases axis (dimension) to which it belongs.

Table 2 indicates the results of this analysis, where all subdivision of paragraphs for each dimension (axis) was high and the largest 0.50 , a standard of acceptance, which means that each of these paragraphs related to dimension, which $\mathrm{T}$

Analysis and Test First Hypothesis:

Tourist companies give attend to society responsibility dimensions:

Table 3 shows the following:

1). All paragraphs have got among the largest means than 5.00 each. Also got significant levels less than 0.04each one, that means was statistically significant. This indicates that all these statistical paragraphs.

2). For all paragraphs, the Mean was 4025 p-value is 0.01 , which it was statistically significant, that is mean to accept the first hypothesis, so that, Tourist companies give attend to sociality responsibility dimensions. 
Table 3. Mean, Std. Deviation, T-test, and p-value to to sociality responsibility dimensions

\begin{tabular}{clcccc}
\hline num & \multicolumn{1}{c}{ paragraph } & mean & Std. Deviation & T-test & Sig. \\
\hline 1 & $\begin{array}{l}\text { From your face, what is the importance of developing } \\
\text { human resources, which includes the social performance of } \\
\text { tourism companies towards the welfare of their employees. }\end{array}$ & 4.25 & 0.60 & 30.30 & 0.00 \\
2 & $\begin{array}{l}\text { From your face, you see the importance of the services } \\
\text { provided by the tourism company to the customers, which } \\
\text { reflects the interest of the tourist company to satisfy the } \\
\text { wishes of customers }\end{array}$ & 5.35 & 0.50 & 30.31 & 0.00 \\
3 & $\begin{array}{l}\text { From your face, consider how important the interaction } \\
\text { with the community is, which includes social activities of } \\
\text { public interest }\end{array}$ & 3.65 & 0.60 & 30.21 & 0.00 \\
Total & & 4.50 & 0.40 & 30.11 & 0.00 \\
\hline
\end{tabular}

\subsubsection{Analysis and Test Second Hypothesis}

Tourist companies develop the relationship with employee:

Table 4 shows the following:

1- With the exception of paragraphs 4 and 7, all other paragraphs have got among the largest means than 4.00 each. Also got significant levels less than 0.04 each one, that means was statistically significant. This indicates that all these statistical paragraphs. Paragraph No. 4, which measure the extent save suitable condition to work, first rank and Mean 4.27. Paragraph No. (7), which measure the extent assist in learn employee's children's came in the last rank within statistically acceptable, and Mean 5.00.

Table 4. Mean Std. deviation, T-test, and p-value to relation with employee

\begin{tabular}{clcccc}
\hline num & \multicolumn{1}{c}{ paragraph } & mean & Std. Deviation & T-test & p-value \\
\hline 4 & $\begin{array}{l}\text { The company organizes training courses for employees } \\
\text { to raise their abilities and efficiency. }\end{array}$ & 5.20 & 0.61 & 33.50 & 0.00 \\
5 & $\begin{array}{l}\text { The company takes into account the disparities in the } \\
\text { abilities and talents of its employees by providing } \\
\text { incentives. }\end{array}$ & 5.30 & 0.50 & 30.20 & 0.00 \\
$\quad \begin{array}{l}\text { The company follows an upgrade policy that recognizes } \\
\text { the abilities and skills of employees and achieves equal } \\
\text { opportunities for promotion. }\end{array}$ & 5.32 & 0.52 & 30.25 & 0.00 \\
7 & The Company provides suitable working conditions. & 5.45 & 0.50 & 17.30 & 0.00 \\
Total & & 5.35 & 0.53 & 25.20 & 0.00 \\
\hline
\end{tabular}

\subsubsection{Analysis and Test Fourth Hypothesis}

Tourist companies develop the relationship with Local society:

Table 5 shows the following:

1). With the exception of paragraph 9, all other paragraphs have got among the largest means than 4.00 each. Also got p-value less than 0.05 each one, that means was statistically significant. This indicates that all these statistical paragraphs.

2). Paragraph No. (10), that got mean less than $\mathbf{3 . 0 0}$, which means it is not statistically significant.

3). All paragraphs together Mean reached 4.25 and p-value 0.00 , which means that has statistically significant which that accepted second hypotheses, which means that is Tourist companies develop the relationship with Local society. 
Table 5. Mean Std. deviation, T-test, and p-value to local society

\begin{tabular}{llllll}
\hline num & paragraph & mean & Std. Deviation & T-test & p-value \\
\hline 8 & $\begin{array}{l}\text { The company provides educational } \\
\text { assistance and grants to members of the } \\
\text { community. }\end{array}$ & 0.50 & 2.25 & 11.30 & 0.00 \\
9 & $\begin{array}{l}\text { The company contributes to the } \\
\text { establishment of schools and health centers. } \\
\text { The company supports universities and local } \\
\text { community colleges (laboratory equipment, } \\
10\end{array}$ & & 2.55 & 10.23 & 0.00 \\
& $\begin{array}{l}\text { computer rooms, etc.). } \\
\text { The tourism company donates to charities, } \\
\text { cultural centers and sports clubs. }\end{array}$ & 0.30 & 2.30 & 10.21 & 0.00 \\
Total & 0.45 & 2.35 & 10.23 & 0.00 \\
\hline
\end{tabular}

\section{Results}

1). The study found that tourism companies give importance to areas of social responsibility.

2). The study found that tourism companies are developing the relationship with employees in tourism companies.

3). The study concluded that tourism companies develop the relationship with the local community.

\section{Recommendations}

1). The study recommends that tourism companies benefit from the experiences of other international companies in the field of social responsibility.

2). The study recommends that tourism companies implement social responsibility in line with sustainable development approaches.

3). The study recommends that tourist companies amend laws and regulations and include them in the social responsibility implementation regulations.

4). The study recommends that tourism companies need the attention of the media to raise awareness of the culture of social responsibility.

\section{References}

Abdulmajid, B.S. (2018). Multinational Commercial Companies and Social Responsibility. Journal of Ijtihad for Legal and Economic Studies, 7(1), 221-249. Algeria.

Abu Al Azm, F. (2005). Obstacles to Environmental Disclosure in Financial Reports: The State of the Arab Republic of Egypt. Journal of Public Administration, 45(1).

Ghalebi, T.M., \& Ameri, S. (2005). Social Responsibility and Business Ethics: Business and Society. Dar Wael Publishing, Amman, Jordan.

Gouda, A.H., Sheikh, E., \& Sabo, S. (2009). The extent of accountability in Jordanian hotels: a field study. Zarqa locality for research and humanitarian studies, 9(9), 23-49.

Hanna F. et al. (2016). Social Responsibility and its Reflection on the Ethics of Tourism Work: A Proposal for the Charter of Business Ethics in Tourism Companies in Egypt. International Journal of Tourism, Heritage and Hotels, 10(1). Egypt.

Mohammed, F. (2010). Corporate Social Responsibility and its Role in Consumer Protection, 3(5), 102-119. Algeria.

Naima, Y. (2011). Models of some international and Islamic companies in the consolidation of social responsibility. Journal of Finance and Markets, 1(2), 33-60. Algeria.

Yahia, Z. et al. (2002). The Importance of Accounting Information on Social Responsibility in the Financial Analysis Process by applying to Al-Khazer Company for the Production of Structural Materials. Rafidain Development Journal, 24(67). 